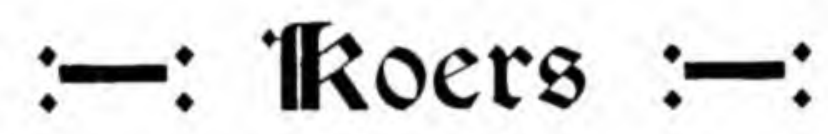

TWEEMAANDELIKSE TYDSKRIF

\title{
Die Akademiese Opgeleides en die Toekoms.
}

(Toespraak by geleentheid van die Gradedag van die P.U. vir C.H.O. op 13 April 1957, deur Sy Edele dr. H. F. Verwoerd).

Nie 'n plegtige referaat nie, maar 'n boodskap met die oog op die toekoms, is die doel van die paar woorde wat by hierdie geleentheid aan u gerig word.

Dit geld 'n nabye toekorns wat ter sprake is, nl. die paar dekades tot die jaar 2000. Diegene wat vandag grade ontvang sal waarskynlik vir 'n groot gedeelte nog in die krag van hul lewens wees. Sommige mag op verskillende terreine leiers wees. Dit is alles ook waar van die kinders wat nou lewe van my eie geslag. Ons kleinkinders wat ons alreeds bevoorreg is om te troetel, sal dan skaars middeljarig wees soos die lewensduur van mense dan vermoedelik sal wees. Hier word dus nie gepraat van 'n verantwoordelikheid teenoor vae, ongebore geslagte nie, maar almal hier teenwoordig is self regstreeks betrokke by wat in hierdie toekomsperiode sal gebeur, en die meeste sal dit persoonlik meemaak. 
Die uitgangspunt is ' $n$ vraag. Wat sal die akademies opgeleides van vandag wêrd wees vir die blanke volk van Suid-Afrika in hierdie toekoms?

Die antwoord op hierdie vraag sal op die ou end die duidelikste wees as deur 'n paar grepe in die verlede nagegaan word wat die geleerdes van die Afrikanervolk toe vir hom beteken het of nie beteken het nie.

Die eerste kan ' $n$ blik gewerp word op die periode van naastenby 1870 tot 1920 . Toe was die volk van herkoms, inbors en natuurlike aanleg eersterangs. Tegelykertyd was dit, veral aan die begin van die tydperk, vir 'n groot gedeelte minder gekultureerd, selfs minder geletterd.

Onder daardie omstandighede was dit 'n ramp vir die destydse Afrikanervolk wanneer 'n jong geleerde, uit sy midde gebore, met opoffering sover gebring, sosizal en intellektueel ontuis begin voel het onder, en sy rug gedraai het op, sy volksgenote, en dit as die kroon op sy ontwikkeling beskou het indien hy opgeneem geword het in die geledere van 'n vreemde, ouere, sogenaamd meer beskaafde, volk, d.w.s. wanneer hy verengels of vereuropees het. Hy het dan immers nie alleen gesoek om homself te verlustig in die geselskap van, of werkgenootskap met, die vreemde nie, maar het neergesien op sy volksgenote, sy kerk, sy ta:al, sy natuurlike maatskaplike kringe, sy ouers en familie, en op die politieke en kulturele stryd waarmee hy hom moes vereenselwig het. Hierdie geskoolde wou opgaan in die vreemde omdat hy dit hoër geag het. Sodoende het hy doodseker waardeloos vir sy volk geword-watter waarde of gebrek aan waarde hy ook al vir sy nuwe kring gehad het. Sommige het positief volksvyandelik geword, dikwels uit 'n minderwaardigheidsgevoel en 'n valse skaamte oor die eie herkoms.

Die Afrikanervolk het egter destyds groot behoefte aan die trou en bystand van sy jong ontwikkeldes gehad. Dit was van lewensbelang dat hulle by hul volk ingelyf sou bly. Hulle moes hul eie natuurlike gemeenskap nie minag en verlaat nie, maar eer en dien. Op alle terreine moes hulle deel hê aan die strewe van kerk, volk, taal en wetenskap; ja, hulle moes die leiding neem. So sou hulle die hele gemeenskap intellektueel en andersins help ophef. Die volk kan alleen as 'n geheel kultureel groei as dit geskied het saam met, en op die spoor van, dié denkers en geskooldes wat gebore en getoë was in sy midde en wat dus op alle terreine sy selfaanvaarde leiers kon wees. 
Gelukkig het die eerste neiging in die vroeë jare van genoemde periode geleidelik, en al meer in die later deel daarvan, oorgeslaan na die tweede neiging. Die opstaan van die volk uit die as van sy materiële nederlae-verarm en met land en vryheid verlore - was te danke aan hierdie oorwinning van die gees. Die hoë peil van die kulturele en politieke triomfe, daarna voortgeplant op ekonomiese gebied, was die vrug van die samewerking van sulke leiers op allerhande gebiede, gewapen met kennis, toegewy and die eie nasie.

Hoe verlore moes die toekoms van die Afrikanerdom nie soms vir die gewone man voorgekom het nie! Die blanke bevolking was klein en omring deur ' $n$ oorweldigende massa van die destydse nie-blanke barbaredom, wat gedreig het om die klein gemeenskap te verdelg. Hierdie klein gemeenskap was boonop deur afstand, geestelike isolasie en die aard van sy stryd om bestaan afgeskei van die wyere Europese kultuurlewe van sy tyd. Sy enigste kontakpunt-en teenstander!was die toenmalige magtige Engelse Ryk met 'n alles-insuigende kultuur. Dit het dan ook sy staat verslaan en sy kinders deur skool en universiteit probeer insluk. Hoe verlore moes alles nie gelyk het nie!

Maar wonder bo wonder: toe die jong geleerde met sy volk bly saamstaan, verdwyn alle rede tot vrees of tot moedeloosheid. Die gees kon terugwen wat kleinheid van getalle en die geringe fisiese mag van die staat verloor het. Oor die herrese volk se groeiende $\mathrm{krag}$, voortbestaansmoontlikheid en selfs heerskappy in eie land was daar, nieteenstaande sulke voorafgaande omstandighede, geen twyfel meer denkbaar nie.

Uit hierdie eerste periode blyk ondubbelsinnig: die waarde van die volksgetroue en volksverbonde kundige, sowel as die reg op geloof en vertroue in enige donkere uur.

Die volgende tydvak, nl. van ongeveer 1920 tot nou, hou nie soseer 'n les vir die toekoms in nie, maar dit moet in die regte lig gesien word om aie besef te laat posvat dat wat die saak onder behandeling betref, 'n nuwe periode net begin. Nou was die Afrikanerdom-ja die hele twee-rassige blankedom van Suid-Afrika-op 'n hoë kultuurpeil soos alle kultuurvolke. Die lewe was ryk en ryp. Wat die Afrikaner betref was sy eie taal algemeen erken en geëer. As instrument was dit bruikbaar gemaak vir alle doeleindes, en geskik as draer, vertolker en verryker van die hoogste wetenskap en kennis. Sy letterkunde en koerante, sy denkers en sprekers, sy kunstenaars en toneel-alles en almal wat kul- 
tuurlewe meebring-het die besitting van die hele volk geword, en nie net van uitverkore enkelinge nie.

In hierdie rustiger vloeiende lewensstroom was die taak van die opgeleide of geleerde mens eenvoudiger. Hy moes nie meer soos tevore aan die stryd om die eie volk se verheffing deelneem nie. Syne was nou die rol van die voortdurende draer en verryker van kennis en van wat lewensvreugde gee aan die eie volk. Hy kon sy taak verrig, hetsy uit eie skeppingswerk of deur oor te dra en vir sy volksgenote eie te ma.ak dit wat van ander kultuurvolke gedurig geërf mag word. Die gemeenskap is gedien wanneer dit gelei is om saam met die uitgelesenes die bereikte kultuurpeil hoog te hou. Midde in hul eie volk arbeidende, he $t$ die vakkundig-onderlegdes dit selfs steeds hoër gevoer.

Vandag gaan hierdie tyd van rus en opbou egter verby. Teeds is die eerste tekens daar van 'n nuwe wêreld wat gedagtestromings or.al veroorsaak, waarvan die uiteindelike uitwerking ingrypender mag wees as die nuwe denkbeelde van die Renaissance of na die Franse Rewolusie.

Die uiterlike faktore wat die omwenteling in die gedagtes, lewenswyse, magsverdeling, rasseverhoudings en staatsorganisasie veroorsaak, is welbekend. Daar is eerstens die geweldige bevolkingsgroei van die nie-blanke volkere. Die opvallendste voorbeeld is China, waarvan die bevolking binne afsienbare tyd byna die helfte van die mensdom k.an tel. Oral in Asië en Afrika is dié groei egter ook ontstellend vinnig. Tweedens is nasionale ontwaking onder die nie-blanke volke en die skepping van onafhanklike state, een na die ander in steeds sneller stygende mate, aan die orde van die dag. Daarmee hang saam as derde faktor: hul vooruitgang deur die aanname van Westerse tegnieke en organisasie. Uit dit alles vloei die vierde faktor voort, nl. die stryd om hul bondgenootskap en guns deur Rusland en sy aanhangers aan dis een kant teen die Verenigde State en die Westerse lande aan die ander kant. Hulle ding mee om die vriendskap en steun van lande in die Ooste - met Indië, China en Japan voorop-van die Arabiese state, van Egipte. Die nuutste soektog na invloedsfere is in Midde-Afrika. Hierdie stryd dra nie net die karakter van magstrewe teen magstrewe nie. Dit is in die eerste plek 'n botsing van ideë-rigting teen ideë-rigting. Dit is 'n stryd om die gees van die mens. Wie dié stryd om die gees van die mens wen, sal die wêreld regeer.

Vir Suid-Afrika is laasgenoemde stryd juis van die allergrootste belang. Die Kommunisme propageer immers die leer van gelykmaking, 
selfs eenwording, van alle mense en alle stelsels. Verskille tussen state, nasies en rasse-teoreties selfs persone-sou moet verdwyn. Indiwidualiteit van mense of volkere sou nie van belang wees nie. Onder 'n Kommunistiese orde sou almal in een eenheid ingelyf kan word en sou, minstens teoreties, alle verskille moet verdwyn. Daarenteen het die Westerse uitkyk steeds berus op die erkenning van elkeen se reg tot 'n eie bestaan, ' $n$ eie indiwidualiteit. Vir nasies het dit beteken die reg op 'n eiesoortige, aparte ontwikkeling; die behoud van elke nasie se eie wese en die geloof dat die mensdom verryk word deur die verskille en die geleentheid tot eie ontwikkeling op eie grondslae. Dit hoef geen betoog nie dat in Suid-Afrik:a die een uitkyk tot 'n bittere stryd om bestaan en heerskappy tussen blanke en Bantoe moet lei, terwyl die ander vrede en samewerking kan bring, omdat aan elkeen eie lewensruimte en eie ontwikkelingstempo, en die voortbou op eie tradisies met eic leiers aan die spits, gegun word.

Helaas! Die treurspel wat afgespeel word is dat die Weste bereid skyn te wees om sy ideë-rigting prys te gee in hierdie bieëry om die guns van die nie-blanke volkere. Miskien word dit nie helder besef nie, maar blykbaar het ky die Westerse moondhede die wanbegrip posgevat d t. Rusland oorbie moet word in eie munt, nl. met gelykstellingsbeloftes, die verskaffing van die middels tot dieselfde lewenswyse en 'n toekenning van die reg om byna onbeperkte eise te stel, ann ander nasies, onafhanklik daarvan of hulle tot die vervulling van gepaardgaande pligte opgewasse is of nie. Ongelukkig word nie begryp nie dat dit juis vir sulke jong state a:antrekliker kon wees om naas materiële hulp alleen gelant te word om die eie bestemming uit te werk, en om van binne uit selfstandig te groei, liewer dan om dadelik ingesleep te word in 'n internasionale maalstroom waarin die pas verworwe selfstandigheid en indiwidualiteit die slıgoffer kan word deur weer verswelg te word. Die Weste probeer nie om die groter waarde vir onafhanklikheid en eiesoortigheid op die ou end van 'n eie uitkyk van die kleinere en swakkere, wie se ontwikkeling net begin, te stel teen die oorheersing wat volg op die slegs skynbaar antrekliker leer van een word met, en verdwyn in, die stant of die geestelike besit van die migtige nie. Wie, wat homself net gevind het, sal dadelik satelliet wil word as hom die nodige insig gegee is?

Hierdie mistasting van die Weste in sy strewe om die sterkere te bly, het die uitgangspunt geword van 'n gedagtestroming wat aangedui 
kon word met benamings soos die liberalisme of die geloof in die algemeenheid van menslike regte of wat ook al. Die grondslae hiervan is egter nouliks te onderskei van die grondslae van die Kommunisme. Hierdie geestelike beïnvloeding van die wêreld is inderdaad laasgenoemde se grootste triomf. Dit het selfs deurgedring tot op kerklike gebied, waar onder invloed van 'n Wêreldraad gestreef word na die wegvee van alles wat indiwidueel-menslik of nasionaal is, en dus verskille wek, sodat alleen die allerbreedste beginsels erken word. Selfs kerke in Kommunistiese lande wat deur laasgenoemde se leer beïnvloed is, moet dit kan anvaar. Op die ou end geld ook op hierdie konserwatiefste terrein van die menslike denke die gelykvormigheid van alle mense en die prysgawe van eiesoortige antwikkeling met soewereiniteit in eie kring.

Hierdie wêreldgees begin deurdring na Suid-Afrika. Dit kom voor in sommige universiteite, by sommige dosente en studente. Ook andere wil as intellektueles bekend staan deur vorme van liberalisme te predik. Daarmee is die kern van hierdie betoog bereik: so 'n houding is weer 'n geestelike oorgawe aan die vreemde, aan wat as groter, meer wêreldwys, breër van uitkyk voorgestel word-presies net soos in die eerste periode hierbo geskets. Vir Suid-Afrika sal so 'n oorgawe deur sy denkers en leiers aan die wêreldstroming egter gevaarliker en nog dodeliker wees as wat destyds die geval was.

In die ander lande bly dit immers net teorie, filosofiese leerstellings, wat inpas by die mikpunte van hul internasionale politiek, en eie belang. Hul bevolkings is een-rassig of hul blanke bevolkings kan, soos in die V.S.A., sonder te groot kwetsuur hul nie-blanke bestanddele mettertyd absorbeer. Binnenslands bly die bestaan en aard van hul bevolkings onaangetas. Indien iets prysgegee word aan gebruike of uitkyk, geskied dit by enkelinge in die verre buiteland. Enige ideërigting kan, selfs net as begeleier van 'n proefneming om staatkundige belange te dien, sonder skade vir die eie volk aangehang word.

In Suid-Afrika, daarenteen, moet uit sulke teorieë die praktyk volg, 'n hele omwenteling wat nòg vir die blanke nòg vir die Bantoe voordeel of veiligheid kan beteken. Die Unie en Suid-Rhodesië, byna die enigste lande waar so 'n leer die selfmoord van die blanke nasie inhou, kan hulle dus nie blindelings laat meesleur in hierdie stroom nie.

Daaruit volg die antwoord op die vraag aan die begin gestel, en die boodskap. Die akademies opgeleides van vandag sal net iets werd wees vir die blanke volk van Suid-Afrika--bestaande uit beide Afri- 
kaans- en Engelstaliges-indien hulle hul denke, navorsing en werk in hierdie stryd om lewe en dood verbonde hou met hul eie nasie se welsyn,soos die roemrykes van die eerste periode. Hul denke en werk moet geanker bly in hul eie volk se lewe. Hulle moet aan die ou, natuurlike en beproefde Westerse uitkyk ten opsigte van die voordele van eie indiwidualiteit en die reg op eiesoortige ontwikkeling vashou. Hulle moet soek na die uitweg waarvolgens die blanke en die nie-blanke elk sodanig in eie kring sy regte apart kan beoefen dat nòg die een nòg die ander die ander opsluk of sy aard vernietig. Die nuwe wêreld-denkmode-want dit is niks hoër nie-mag niemand geestelik laat vervreemd raak nie.

Daar is diegene wat tot moedeloosheid neig weens die genoemde verskjnsel dat daar reeds diegene is wat die wapens neerlê, of vanweë die geestelike geïsoleerdheid van Suid-Afrika in hierdie opsig in 'n wêreld met teenoorgestelde belange. Tog is moedverloor nie geregverdig nie. Meermale het 'n denker of 'n hervormer op geestelike of kulturele gebied alleen gestaan vir 'n idee wat reg was en dit het triomfeer. In die eerste periode hierbo genoem was ook die massa teen die klein gemeenskap en was daar isolasie, vyandigheid en neerlaag, maar die geesteskrag van die regte uitkyk het gewen. So kan dit weer wees as die draer van kennis in Suidelike Afrika saam bly staan met die volk uit wie hy gespruit het. Daardeur sal die redding van beide Blanke en Bantoe, maar naas en apart van mekaar, bewerkstellig kan word. Die kleine Suid-Afrika kan aan die volkere van die wêreld demonstreer dat gesonde state- en rasseverhoudings nie tot stand gebring kan word deur inslukking of gelykmaking nie, maar alleen deur vir elkeen te gun en te gee: ' $n$ eie bestaan op die wyse wat beste by hom pas. 